\title{
Hexavalent chromium removal using aerobic activated sludge batch systems added with powdered activated carbon
}

\author{
A Micaela Ferro Orozco ${ }^{1}$, Edgardo M Contreras ${ }^{1 *}$, Nora C Bertola ${ }^{1,2}$, Noemi E Zaritzky ${ }^{1,2}$ \\ ${ }^{1}$ Centro de Investigación y Desarrollo en Criotecnología de Alimentos (CIDCA) - CONICET - Fac. de Cs. Exactas - UNLP. 47 y 116 \\ (1900) La Plata, Argentina \\ ${ }^{2}$ Fac. de Ingeniería - UNLP
}

\begin{abstract}
The addition of powdered activated carbon (PAC) has been proposed as a suitable technique to protect activated sludge against toxic wastewaters. However, the literature data describing the combined effect of PAC addition on $\mathrm{Cr}(\mathrm{VI})$ removal using activated sludge are scarce. The objectives of this study were to investigate the effect of the initial $\mathrm{Cr}(\mathrm{VI})$ concentration, $\mathrm{PAC}$ and an electron donor addition on $\mathrm{Cr}(\mathrm{VI})$ removal using aerobic activated sludge batch reactors.

The following $\mathrm{Cr}(\mathrm{VI})$ removal systems were tested: activated sludge alone; activated sludge with an external electron donor ( $5 \mathrm{~g} / \ell$ of lactose); activated sludge with PAC addition (4 g/ $/$ ); activated sludge with both PAC and lactose; and PAC alone. The results reported here showed that activated sludges are capable of removing $\mathrm{Cr}(\mathrm{VI})$ via its reduction to $\mathrm{Cr}(\mathrm{III})$ only if a suitable electron donor (such as lactose) is available. For initial $\mathrm{Cr}(\mathrm{VI})$ concentration lower than $10 \mathrm{mg} / \ell$, biomass alone can remove $100 \%$ of the $\mathrm{Cr}(\mathrm{VI})$. However, for higher initial $\mathrm{Cr}(\mathrm{VI})$ concentrations, removal efficiencies $\left(\mathrm{R}_{\mathrm{E}}\right)$ of the system with PAC were higher than $\mathrm{R}_{\mathrm{E}}$ corresponding to the system without PAC. In addition, as the initial $\mathrm{Cr}(\mathrm{VI})$ concentration increased, the rate of $\mathrm{Cr}(\mathrm{VI})$ removal and $\mathrm{R}_{\mathrm{E}}$ values decreased reflecting loss of metabolic activity of the activated sludge due to the toxicity of $\mathrm{Cr}(\mathrm{VI})$; however, this inhibition was less in systems with PAC. Whereas the removal of $\mathrm{Cr}(\mathrm{VI})$ using powdered activated carbon (PAC) alone is negligible, the addition of PAC can improve the biological reduction of $\mathrm{Cr}(\mathrm{VI})$ due to the stimulating or protective effect against the $\mathrm{Cr}(\mathrm{VI})$ toxicity. This protective effect was also observed in respiratory activity of the biomass.
\end{abstract}

Keywords: activated sludge, powdered activated carbon, hexavalent chromium, trivalent chromium

\section{Introduction}

Heavy metal residues in contaminated habitats may accumulate in micro-organisms, aquatic flora and fauna, which in turn, may enter the human food chain and result in health problems. Among these metals, chromium and its compounds are placed on the priority list of toxic chemicals of many countries including the USA, the UK and Canada (Hedgecott, 1994). Chromium is usually found in the environment in oxidation states (III) and (VI). Each of the above-mentioned oxidation states has different biological and chemical properties. Typical hexavalent chromium compounds are highly soluble chromates $\left(\mathrm{CrO}_{4}^{2-}, \mathrm{HCrO}_{4}^{-}\right)$ and dichromates $\left(\mathrm{Cr}_{2} \mathrm{O}_{7}^{2-}\right)$; these compounds are toxic and carcinogenic for a variety of organisms due to their strong oxidising capability (USEPA, 1998a). Trivalent chromium can form both anionic (e.g. $\left.\mathrm{Cr}(\mathrm{OH})_{4}{ }^{-}, \mathrm{CrCl}_{6}{ }^{3-}\right)$ or cationic (e.g. $\mathrm{Cr}\left(\mathrm{H}_{2} \mathrm{O}\right)_{6}{ }^{3+}$, $\left.\mathrm{Cr}(\mathrm{OH})^{2+}, \mathrm{Cr}(\mathrm{OH})_{2}^{+}\right)$compounds. These compounds are considered to be non-labile, inert species in the environment and essential for mammals in trace amounts (USEPA, 1998b). Due to its common presence in effluent discharge from steelworks, chromium electroplating, leather tanning and chemical manufacturing industries, chromium is often detected in sewage plants that treat a combination of industrial and municipal wastewater.

Conventional methods for removing $\mathrm{Cr}(\mathrm{VI})$ include chemical reduction to $\mathrm{Cr}$ (III) followed by a precipitation step under alkaline conditions (Beukes et al., 2000; Bojic et al., 2004) or

* To whom all correspondence should be addressed.

孟 +54-221-4254853; fax: +54-221-4254853;

e-mail: econtrer@quimica.unlp.edu.ar

Received 19 May 2006; accepted in revised form 21 November 2006. adsorption using chitosan (Schmuhl et al., 2001) or activated carbon (Demirbas et al., 2004). All these methods have their own disadvantages; alkali precipitation produces large quantities of chemical sludge, whereas ion exchange and adsorption are generally costly and less specific for $\mathrm{Cr}(\mathrm{VI})$ removal in the presence of other ions. The search for new technologies has focused attention on the biotransformation of metals by using micro-organisms. A great number of bacterial genera were described as capable of reducing $\mathrm{Cr}(\mathrm{VI})$ to $\mathrm{Cr}(\mathrm{III})$ including Escherichia (Shen and Wang, 1994; Wang and Shen, 1997), Pseudomonas (Bopp and Ehrlich, 1988; Ishibashi et al., 1990; Wang and Xiao, 1995), Bacillus (Wang and Xiao, 1995; Garbisu et al., 1998; Philip et al., 1998), Enterobacter (Wang et al., 1990; Clark, 1994; Rege et al., 1997), Desulfovibrio (Lovley and Phillips, 1994), Shewanella (Myers et al., 2000), Serratia (Mondaca et al., 2002), Rhodobacter (Nepple et al., 2002) and Arthrobacter (Asatiani et al., 2004). The main disadvantage of using pure cultures to remove $\mathrm{Cr}(\mathrm{VI})$ compounds is related to the use of sterile conditions to prevent the external microbial contamination. For this reason the removal of $\mathrm{Cr}(\mathrm{VI})$ using activated sludge is a promising technique.

In general, biological treatment is negatively affected by the heavy metals due to their toxicity for micro-organisms. However, the literature data with respect to the toxic effect of $\mathrm{Cr}(\mathrm{VI})$ on the activated sludge process (e.g. substrate removal, respiration activity, or bacterial growth) are controversial. For example, Stasinakis et al. (2002) reported that Cr(VI) concentrations higher than $10 \mathrm{mg} / \ell$ inhibited the growth of non-acclimatised activated sludge. Chua (1998) found that the effect of 0.05 $\mathrm{mg} / \ell$ of $\mathrm{Cr}(\mathrm{VI})$ on the performance of sequencing batch reactors was a function of the sludge age. Yetis et al. (1999) reported 
the stimulation of an acclimatised sludge in the presence of 25 $\mathrm{mgCr}(\mathrm{VI}) / \ell$. Vankova et al. (1999) found that the $\mathrm{Cr}(\mathrm{VI})$ concentration that inhibited $50 \%$ of the respiration rate ranged between 40 and $90 \mathrm{mg} / \ell$. However, Madoni et al. (1999) reported that $100 \mathrm{mgCr}(\mathrm{VI}) / \ell$ reduced the activated sludge respiration rate by only $21.5 \%$.

The addition of powdered activated carbon (PAC) into the aeration basin has been proposed as a suitable technique to protect the activated sludge against toxic wastewaters (Orshansky and Narkis, 1997; Costa and Márquez, 1998). However, data reported in the literature describing the combined effect of PAC addition on $\mathrm{Cr}(\mathrm{VI})$ removal using activated sludge are scarce.

The objectives of this study were to investigate the effect of the initial $\mathrm{Cr}(\mathrm{VI})$ concentration, PAC and an electron donor addition on $\mathrm{Cr}(\mathrm{VI})$ removal using batch reactors of aerobic activated sludge. Five different $\mathrm{Cr}(\mathrm{VI})$ removal systems were analysed:

(1) Activated sludge alone

(2) Activated sludge with an external electron donor

(3) Activated sludge with PAC addition

(4) Activated sludge with both PAC and an electron donor

(5) PAC alone.

\section{Materials and methods}

\section{Activated sludge}

The activated sludge used in this experimental set-up was cultured in a laboratory-scale $(4.5 \ell)$ Eckenfelder aerobic reactor type. The plant was fed with a synthetic wastewater containing dehydrated cheese whey (1 $500 \mathrm{mg}),\left(\mathrm{NH}_{4}\right)_{2} \mathrm{SO}_{4}(94 \mathrm{mg})$ and $\mathrm{NaHCO}_{3}(1030 \mathrm{mg})$ dissolved in $1 \ell$ of tap water. The C: N: $\mathrm{P}$ ratio of the used cheese whey was 100:7:0.6 (Bertola et al., 2001). Hydraulic retention time was $2 \mathrm{~d}$; sludge age was maintained at $45 \mathrm{~d}$ by the daily wasting of mixed liquor directly from the reactor. During the experiments the temperature of the reactor was kept at $19 \pm 2^{\circ} \mathrm{C}$; under steady state conditions dissolved oxygen (DO) concentration was above $5 \mathrm{mg} / \ell ; \mathrm{pH}$ was $7.5 \pm 0.4$; soluble chemical oxygen demand (COD) in the effluent ranged between 30 and $80 \mathrm{mg} / \ell$; and the biomass concentration ranged from 3 500 to $4000 \mathrm{mgCOD} / \ell$.

\section{Chromium (VI) removal potential of the used activated sludge}

In order to determine if the micro-organisms present in the activated sludge were capable of reducing hexavalent chromium, a $\mathrm{Cr}(\mathrm{VI})$ removal assay using an activated sludge batch reactor with lactose $(5 \mathrm{~g} / \ell)$ as substrate was performed; in this experiment the biomass concentration was $1800 \mathrm{mgCOD} / \ell$ and the initial $\mathrm{Cr}(\mathrm{VI})$ concentration was $26 \mathrm{mgCr} / \ell$. Samples were taken at predetermined time intervals and they were centrifuged at $13000 \mathrm{r} / \mathrm{min}$ for $5 \mathrm{~min}$ (Eppendorf centrifuge 5415C, Hamburg, Germany) in order to eliminate the biomass; thereafter the $\mathrm{Cr}(\mathrm{VI})$ concentration in the supernatant was determined. At $67 \mathrm{~h}$, the biomass was harvested by centrifugation; the supernatant was maintained under the same aeration and agitation conditions and the $\mathrm{Cr}(\mathrm{VI})$ concentration was monitored up to $200 \mathrm{~h}$. All measurements were performed in duplicate.

\section{$\mathrm{Cr}(\mathrm{VI})$ removal experiments}

Batch Cr(VI) removal assays were performed in $0.5 \ell$ aerated vessels at a constant temperature $\left(20^{\circ} \mathrm{C} \pm 2^{\circ} \mathrm{C}\right)$ and initial $\mathrm{pH}=$

\begin{tabular}{|l|c|}
\hline \multicolumn{2}{|c|}{ TABLE 1 } \\
Characteristics of the PAC used \\
\hline Properties & Value \\
\hline Surface area, BET $\left(\mathrm{N}_{2} / 77^{\circ} \mathrm{K}\right)$ & $889 \mathrm{~m}^{2} / \mathrm{g}$ \\
\hline Methylene blue adsorption & $260 \mathrm{mg} / \mathrm{g}$ \\
\hline Iodine adsorption & $800 \mathrm{mg} / \mathrm{g}$ \\
\hline Bulk density & $0.29 \mathrm{~g} / \mathrm{cm}^{3}$ \\
\hline Moisture & $12 \%$ \\
\hline pH (1\% suspension) & $6.0-8.0$ \\
\hline $\begin{array}{l}\text { Screen analysis, } \\
\text { Passes mesh \#325 }\end{array}$ & $60-80 \% \mathrm{wt}$ \\
\hline
\end{tabular}

$7.0 \pm 0.1$; this $\mathrm{pH}$ was selected because it is the optimum value for the metabolic activity of most of the micro-organisms that are present in a typical activated sludge. The following $\mathrm{Cr}(\mathrm{VI})$ removal systems were tested:

- Activated sludge alone

- Activated sludge with an external electron donor (lactose $5 \mathrm{~g} / \ell$ )

- Activated sludge with PAC addition

- Activated sludge with both PAC and lactose

- PAC alone.

The latter assay was performed using the supernatant of the centrifuged outlet stream of the treatment plant; the final soluble COD ranged between 30 and $80 \mathrm{mg} / \ell$. Lactose was chosen as the electron donor because this sugar was the main component of the cheese whey used to feed the wastewater treatment plant. For the $\mathrm{Cr}(\mathrm{VI})$ removal systems using activated sludge (Systems 1 to 4) the biomass concentration was $2000 \pm 300 \mathrm{mgCOD} / \ell$. In the experiments with PAC addition (Systems 3 to 5), $4 \mathrm{~g} / \ell$ of a wood based PAC (Clarimex SA, Type 061) was used; Table 1 shows the characteristics of the activated carbon used in the experiments. $\mathrm{Cr}(\mathrm{VI})$ stock solutions were freshly prepared using analytical grade $\mathrm{K}_{2} \mathrm{Cr}_{2} \mathrm{O}_{7}$; tested $\mathrm{Cr}(\mathrm{VI})$ concentrations were $10,25,50$ and $100 \mathrm{mg} / \ell$. All batch experiments lasted about 200h; samples were taken at predetermined time intervals and they were centrifuged at $13000 \mathrm{r} / \mathrm{min}$ for $5 \mathrm{~min}$ (Eppendorf centrifuge 5415C, Hamburg, Germany) to eliminate the biomass and/or PAC, upon which the total chromium and $\mathrm{Cr}(\mathrm{VI})$ concentrations were determined in the supernatant. Soluble Cr(III) concentration was calculated as the difference between total $\mathrm{Cr}$ and soluble $\mathrm{Cr}(\mathrm{VI})$ concentrations. All measurements were performed in duplicate. The $\mathrm{Cr}(\mathrm{VI})$ removal efficiency $\left(\mathrm{R}_{\mathrm{E}}\right)$ of each tested system was calculated using the following expression:

$$
R_{E}=100\left(\frac{C o-C}{C o}\right)
$$

where:

Co and $\mathrm{C}$ were the initial $\mathrm{Cr}(\mathrm{VI})$ and the $\mathrm{Cr}(\mathrm{VI})$

concentration at time $\mathrm{t}$ respectively

\section{Respirometry}

Oxygen uptake rate (OUR) is a widely used index of metabolic activity of aerobic micro-organisms (Vanrolleghem et al., 1994) and has been used to study toxicity of several chemical agents (Ros, 1993; Vanrolleghem et al., 1994). This technique was used to evaluate the effect of $\mathrm{Cr}(\mathrm{VI})$ and $\mathrm{PAC}$ on the microbial respiration. The tested $\mathrm{Cr}(\mathrm{VI})$ concentrations were $0,10,25,50,75$ and 100 $\mathrm{mg} / \ell$; in the systems with PAC the concentration was $4 \mathrm{~g} \mathrm{PAC} / \ell$.

The respirometer included a vessel containing a polarographic oxygen probe (YSI Incorp., Ohio, USA), an aerator and magnetic stirring; the output of the oxygen probe was connected 
to a computer. OUR was measured by placing $20 \mathrm{~m} \ell$ of the activated sludge suspension in the respirometer. A volume of $1 \mathrm{ml}$ cheese whey solution was added as the oxidisable substrate; after $10 \mathrm{~min}$ the system was aerated during $1 \mathrm{~min}$. Once aeration was stopped, a linear decrease of dissolved oxygen concentration with time was found, OUR being the slope of the line.

The effect of $\mathrm{Cr}(\mathrm{VI})$ on activated sludge respiratory activity was evaluated using the following expression:

$$
\mathrm{Fr}=\frac{\mathrm{OUR}_{(\mathrm{Cr}(\mathrm{VI}))}}{\mathrm{OUR}_{(\text {control })}}
$$

where:

Fr is the bacterial respiratory activity fraction based on determinations of the OUR on untreated samples $\left(\mathrm{OUR}_{\text {(control) }}\right)$ and after the contact with hexavalent chromium $\left(\mathrm{OUR}_{(\mathrm{Cr}(\mathrm{VI}))}\right)$ in the presence or absence of PAC

All assays were performed in duplicate.

\section{Analytical methods}

$\mathrm{Cr}(\mathrm{VI})$ in the supernatant was determined by the diphenylcarbazide method (Standard Methods, 1989). In order to measure the total chromium concentration, supernatants were treated with ammonium persulphate and potassium permanganate to oxidise $\mathrm{Cr}(\mathrm{III})$ to $\mathrm{Cr}(\mathrm{VI})$; $\mathrm{Cr}(\mathrm{III})$ concentration was estimated as the difference between oxidised (total $\mathrm{Cr}$ ) and non-oxidised (Cr(VI)) samples. Precipitated and/or adsorbed (non-soluble) $\mathrm{Cr}$ was calculated as the difference between the initial total $\mathrm{Cr}$ and the total $\mathrm{Cr}$ concentration at time t. The COD was determined using Hach reagents (Hach Company, Loveland, CO). The biomass concentration was determined as COD using a procedure previously developed (Contreras et al., 2002).

\section{Results and discussion}

\section{Chromium (VI) removal potential of the activated sludge used in the experiments}

This experiment was performed to demonstrate that the microorganisms present in the activated sludge were capable of removing $\mathrm{Cr}(\mathrm{VI})$. Figure 1 shows that $\mathrm{Cr}(\mathrm{VI})$ concentration decreased from 26 to $17 \mathrm{mg} / \ell$ within the first $67 \mathrm{~h}$. At this time, the biomass was harvested by centrifugation (indicated by an arrow) and afterwards no subsequent change in $\mathrm{Cr}(\mathrm{VI})$ concentration was observed. As neither detectable adsorption of chromium species, reduction of $\mathrm{Cr}(\mathrm{VI})$ nor the oxidation of $\mathrm{Cr}(\mathrm{III})$ on the vessel walls were produced, this experiment demonstrated that the removal of $\mathrm{Cr}(\mathrm{VI})$ was associated with the presence of the biomass.

\section{Chromium (VI) removal performance of the different systems}

Figure 2 shows an example of $\mathrm{Cr}(\mathrm{VI})$ removal experiments using the different tested systems; in this case the initial $\mathrm{Cr}(\mathrm{VI})$ concentration was $100 \mathrm{mg} / \ell . \mathrm{Cr}(\mathrm{VI})$ removal rates of Systems 1 (activated sludge alone), 3 (activated sludge with PAC), and 5 (PAC alone) were slower than removal rates in System 2 (activated sludge with lactose). In addition, the maximum $\mathrm{Cr}(\mathrm{VI})$ removal rate was obtained in System 4 (activated sludge with lactose and PAC). At $190 \mathrm{~h}$ the $\mathrm{Cr}(\mathrm{VI})$ concentration in Systems 1,3 , and 5 ranged between 90 and $95 \mathrm{mg} / \ell$. However, in Systems 2 and 4, where lactose was added, the Cr(VI) concentrations after $190 \mathrm{~h}$ were 67 and $14 \mathrm{mg} / \ell$ respectively. The results

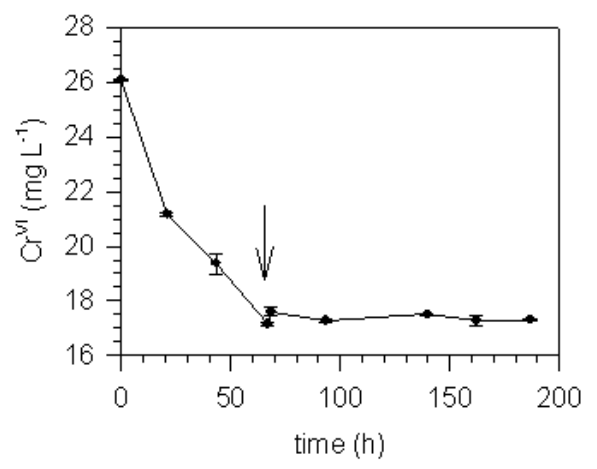

Figure 1

Removal of $\mathrm{Cr}(\mathrm{VI})$ by activated sludge as a function of time in the presence of lactose $(5 \mathrm{~g} / \mathrm{l})$ as the electron donor. The arrow indicates the removal of biomass by centrifugation. Results represent the mean value $\pm S D$ from two determinations.

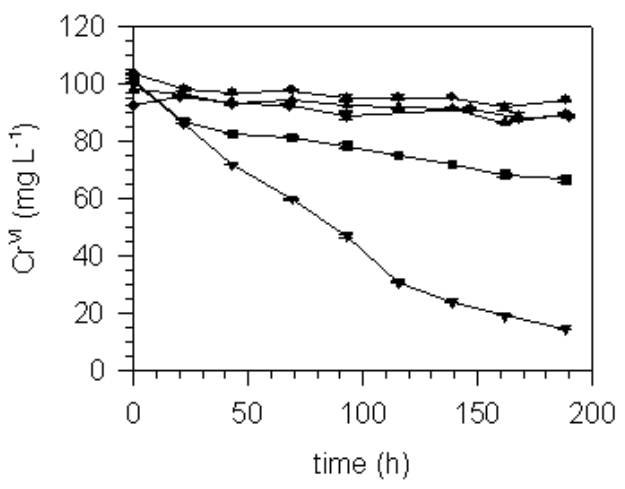

Figure 2

Cr(VI) removal as a function of time: (৩) System 1 (activated sludge), ( System 2 (activated sludge with lactose),

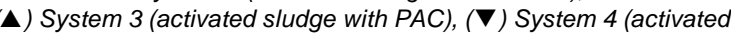
sludge with lactose and PAC), and ( $\bullet$ System 5 (PAC alone). Experimental conditions: Biomass $=2000 \pm 300 \mathrm{mg} C O D / \ell, P A C=4 \mathrm{~g} / \mathrm{l}$, Lactose $=$ $5 \mathrm{~g} / \mathrm{\ell}, \mathrm{Cr}(\mathrm{VI})=100 \mathrm{mg} / \mathrm{l}$, initial $\mathrm{pH}=7.0 \pm 0.1$. Results represent the mean value $\pm S D$ from two determinations.

using different $\mathrm{Cr}(\mathrm{VI})$ initial concentrations showed a similar tendency.

\section{Effect of the electron donor addition (lactose)}

Figure 3 shows the $\mathrm{Cr}(\mathrm{VI})$ removal efficiencies $\left(\mathrm{R}_{\mathrm{E}}\right)$ corresponding to the tested systems as a function of time for different $\mathrm{Cr}(\mathrm{VI})$ initial concentrations. For systems without lactose (Fig. 3a; c) $\mathrm{R}_{\mathrm{E}}$ values were lower than in the systems with lactose (Fig. 3b; d). One of the main mechanisms proposed in the literature for $\mathrm{Cr}(\mathrm{VI})$ removal using biomass (pure and mixed cultures) under aerobic conditions is the reduction of Cr(VI) to Cr(III) (Imai and Gloyna, 1990; Wang and Shen, 1997; Stasinakis et al., 2004). This Cr(VI) reductase activity is generally dependent on the presence of a suitable electron donor (Bopp and Ehrlich, 1988; Philip et al., 1998; Shen and Wang, 1994; 1995; Wang and Shen, 1997; Wang and Xiao, 1995). In our experiments the systems with lactose (Fig. 3b; d) also had higher removal efficiencies than the systems without this sugar (Fig. 3a; c).

\section{Effect of PAC addition}

Figure 2 shows that the rate of $\mathrm{Cr}(\mathrm{VI})$ removal using PAC alone (System 5) was very low; the removal efficiency was lower than $7 \%$ for all the tested initial $\operatorname{Cr}(\mathrm{VI})$ concentrations. However, 


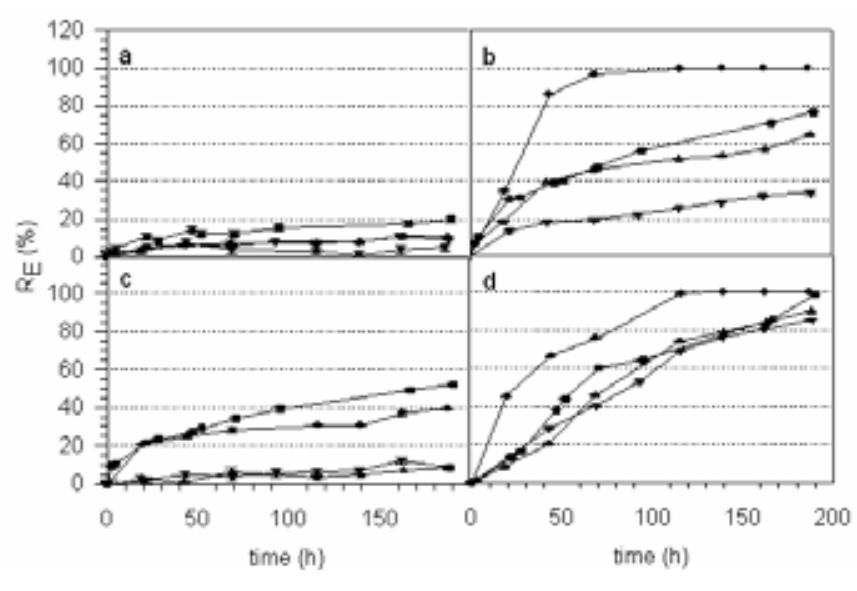

Figure 3

Cr(VI) removal efficiencies $\left(R_{E}\right)$ as a function of time

- $\quad$ System 1 (activated sludge), (a)

- $\quad$ System 2 (activated sludge with lactose) (b)

- $\quad$ System 3 (activated sludge with PAC) (c)

- System 4 (activated sludge with lactose and PAC) (d).

In all cases the initial $\mathrm{Cr}(\mathrm{VI})$ concentrations were: (O) $10 \mathrm{mg} / \ell$, (口) 25

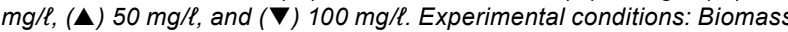

$=2000 \pm 300 \mathrm{mg} \mathrm{COD} / \mathrm{l}, \mathrm{PAC}=4 \mathrm{~g} / \mathrm{l}$, Lactose $=5 \mathrm{~g} / \mathrm{l}$, initial $\mathrm{pH}=7.0 \pm$

0.1 . Results represent the mean value $\pm S D$ from two determinations.

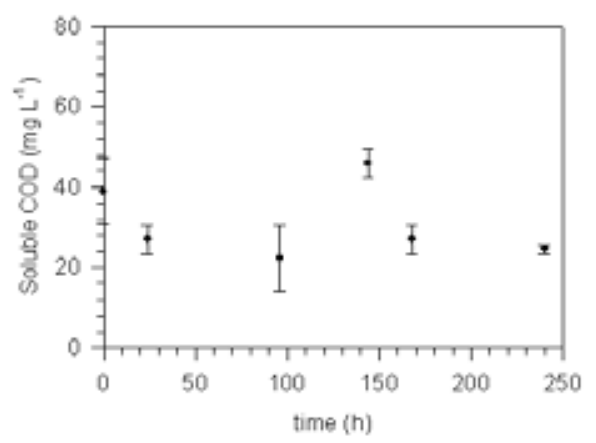

Figure 4

Soluble $C O D$ as a function of time for a PAC suspension $(4 \mathrm{~g} / \ell)$ in distilled water. Results represent the mean value $\pm S D$ from two determinations.

$\mathrm{Cr}(\mathrm{VI})$ removal efficiencies in the presence of biomass with PAC (Fig. 3c; d) were higher than those of the systems without PAC (Fig. 3a; b) for initial C(VI) concentrations higher than $25 \mathrm{mg} / \ell$.

Comparing the systems without lactose, it was observed that the $\mathrm{Cr}(\mathrm{VI})$ removal performance of System 3 (activated sludge with PAC) was higher than $R_{E}$ values of System 1 (activated sludge alone) only for initial $\mathrm{Cr}(\mathrm{VI})$ concentrations lower than $25 \mathrm{mg} / \ell$. When the initial $\mathrm{Cr}(\mathrm{VI})$ concentration was $25 \mathrm{mg} / \ell$, the $R_{E}$ values of the Systems 3 and 1 (both without lactose) determined after $190 \mathrm{~h}$, were 52 and 29\% respectively. However, when the initial $\mathrm{Cr}(\mathrm{VI})$ concentration was $100 \mathrm{mg} / \ell, \mathrm{R}_{\mathrm{E}}$ values were around $10 \%$ for both systems (Fig. 3a;c). In the systems without lactose (Systems 1 and 3), the electron source for the reduction of $\mathrm{Cr}(\mathrm{VI})$ to $\mathrm{Cr}(\mathrm{III})$ could be the biomass itself or the activated carbon. However, Fig. 4 shows that the soluble COD of a PAC suspension $(4 \mathrm{~g} / \ell)$ in distilled water did not increase within the first $240 \mathrm{~h}$; thus, the PAC did not produce any soluble fraction that could be used by the micro-organisms as electron donor. The electrons used by the biomass for the reduction of $\mathrm{Cr}(\mathrm{VI})$ to $\mathrm{Cr}(\mathrm{III})$ in System 3 (activated sludge with PAC without lactose) could be provided by PAC surface groups such as carboxylates, ethers, lactones or quinones (Figueiredo et al., 1999).

In the systems containing lactose, when the initial $\mathrm{Cr}(\mathrm{VI})$
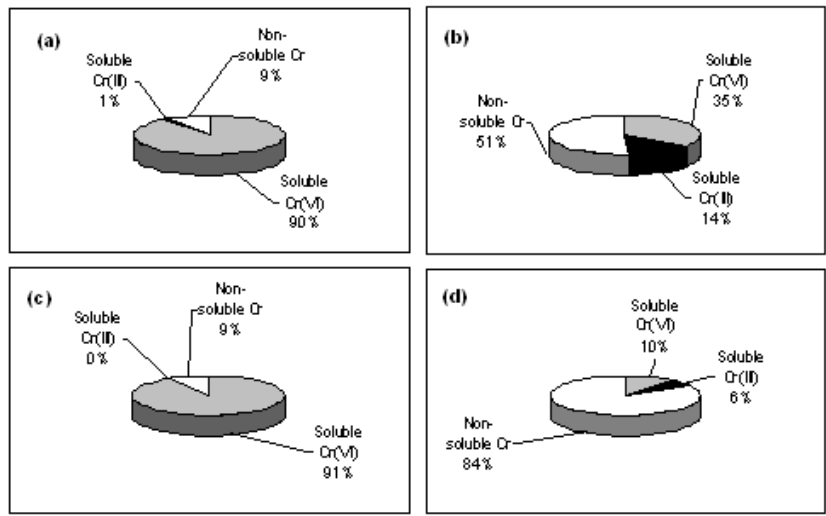

Figure 5

Chromium species distribution of the following Cr removal systems: (a) System 1 (activated sludge); (b) System 2 (activated sludge with lactose); (c) System 3 (activated sludge with PAC); (d) System 4 (activated sludge with lactose and PAC). In all cases the contact time was $190 \mathrm{~h}$ and the initial $\mathrm{Cr}(\mathrm{VI})$ concentration was $50 \mathrm{mg} / \mathrm{\ell}$.

concentration was $10 \mathrm{mg} / \ell$ the $\mathrm{R}_{\mathrm{E}}$ values of both Systems 4 (with PAC) and 2 (without PAC) were $100 \%$. However, for $\operatorname{Cr}(\mathrm{VI})$ initial concentrations higher than $10 \mathrm{mg} / \ell$, it was observed that the capacity to reduce $\mathrm{Cr}(\mathrm{VI})$ in the activated sludge (Fig. 3b) decreased as the initial $\mathrm{Cr}(\mathrm{VI})$ concentration increased, therefore the rate of $\mathrm{Cr}(\mathrm{VI})$ removal and $\mathrm{R}_{\mathrm{E}}$ values decreased reflecting loss of metabolic activity of the activated sludge due to the toxicity of $\mathrm{Cr}(\mathrm{VI})$. In System 2 (biomass with lactose), the $\mathrm{R}_{\mathrm{E}}$ final values (at $190 \mathrm{~h}$ ) were 77,65 and $34 \%$ for the initial $\mathrm{Cr}(\mathrm{VI})$ concentrations of 25,50 and $100 \mathrm{mg} / \ell$ respectively (Fig. 3b). The loss of metabolic activity was observed to a lesser extent when PAC was present; the $R_{E}$ final values for the system containing lactose and PAC (Fig. 3d) were 98, 90 and $86 \%$ when the initial $\mathrm{Cr}(\mathrm{VI})$ concentrations were 25,50 and $100 \mathrm{mg} / \ell$ respectively. These results suggest a protective and/or stimulating effect of the activated carbon on the micro-organisms.

\section{Distribution of the different chromium species in the tested systems}

Total chromium and Cr(VI) concentrations were determined in the supernatant of each system. Soluble Cr(III) concentration was calculated as the difference between total $\mathrm{Cr}$ and soluble $\mathrm{Cr}(\mathrm{VI})$ concentrations. Figure 5 shows the distribution of the chromium species in the different assayed systems: soluble $\mathrm{Cr}(\mathrm{VI})$, soluble $\mathrm{Cr}(\mathrm{III})$ and non-soluble $\mathrm{Cr}$; the last one includes adsorbed and/or precipitated species. As the reduction of $\mathrm{Cr}(\mathrm{VI})$ to $\mathrm{Cr}$ (III) without the presence of an electron donor (lactose) was very slow, a low soluble $\mathrm{Cr}$ (III) concentration was detected in Systems 1 and 3 (without lactose). Whereas at the $\mathrm{pH}$ level used in this study $(7.0 \pm 0.2) \mathrm{Cr}(\mathrm{VI})$ compounds are highly soluble in aqueous solutions, the solubility of $\mathrm{Cr}$ (III) is very low (about $\left.5 \times 10^{-3} \mathrm{mg} \mathrm{Cr} / \ell\right)$ due to the formation of non-soluble species such as $\mathrm{Cr}(\mathrm{OH})_{3}\left(\mathrm{~K}_{\mathrm{sp}}=1.2 \times 10^{-28} \mathrm{M}^{4}\right)$ (Katz and Salem, 1994). However, soluble $\mathrm{Cr}(\mathrm{III})$ concentrations found in most of the tested chromium removal systems (Fig. 5) were higher than the solubility of $\mathrm{Cr}$ (III). These results can be explained by considering that trivalent chromium can form a wide variety of coordination complexes; once formed, these complexes are quite stable in aqueous solutions (Katz and Salem, 1994). Nitrogen-containing compounds such as $\mathrm{NH}_{3}$, amino acids and proteins are potential ligands for the formation of coordination complexes with $\mathrm{Cr}(\mathrm{III})$. As the activated sludge treatment plant was fed with cheese whey, these nitrogen-containing compounds could be present in 
the outlet stream. Therefore, the higher soluble $\mathrm{Cr}$ (III) concentrations found in the tested systems suggested the formation of coordination complexes that increased the $\mathrm{Cr}$ (III) solubility.

Although the highest $\mathrm{Cr}(\mathrm{VI})$ removal was obtained using System 4 (activated sludge with lactose and PAC), the highest soluble Cr(III) concentration was found in System 2 (activated sludge with lactose). This result suggested that in System 4 the potential ligands of $\mathrm{Cr}(\mathrm{III})$ could be adsorbed onto the PAC decreasing the $\mathrm{Cr}(\mathrm{III})$ solubility. Previous experiments performed in our laboratory showed that the specific adsorption of cheese whey onto the used activated carbon was $83 \mathrm{mg}$ COD/ gPAC; thus, the addition of $4 \mathrm{~g}$ PAC/ $\ell$ could potentially adsorb about $332 \mathrm{mg} \mathrm{COD} / \ell$. This value was much higher than the soluble COD in the outlet stream ( 30 to $80 \mathrm{mg} \mathrm{COD} / \ell$ ); therefore all the potential ligands of $\mathrm{Cr}$ (III) could be adsorbed. If this was the case, soluble $\mathrm{Cr}$ (III) concentrations in systems with PAC (System 4) must be lower than in systems without PAC (System 2), in accordance with the experimental observations (Fig. 5).

\section{Protective effect of PAC against $\mathrm{Cr}(\mathrm{VI})$ toxicity in the activated sludge}

Considering that $\mathrm{Cr}(\mathrm{VI})$ removal in System 5 (using PAC alone) was almost negligible (Fig. 2) and that the presence of PAC in Systems 3 and 4 improved the Cr(VI) removal efficiencies (Fig. 3c, d), this improvement cannot be attributed to the presence of the activated carbon itself but to a metabolic stimulation of the biomass or a protective effect of PAC against the $\mathrm{Cr}(\mathrm{VI})$ toxicity.

Different authors reported that different metabolic activities of the activated sludge were stimulated by the addition of PAC in the aeration tanks (Taniguchi et al., 1993; Orshansky and Narkis, 1997; Okada et al., 2000; Morinaga et al., 2003). The stimulation of bacterial activity when cells are adhered on activated carbon may be due to different mechanisms:

(a) The concentration of substrates is high at the surface of the activated carbon (Kalinske, 1972)

(b) Substrates adsorbed on activated carbon can be supplied directly to the adhered bacteria by desorption ( $\mathrm{Li}$ and DiGiano, 1983)

(c) Higher oxygen concentration on activated carbon surface (Kalinske, 1972; Ying and Weber, 1979)

(d) Longer contact times between the cells and adsorbed substrates

(e) The adsorption of inhibitory or toxic substances on the activated carbon surface (Sublette et al., 1982).

Experiments performed in our laboratory showed that the used PAC adsorbed about $17 \mathrm{mg}$ of lactose per gram of activated carbon; therefore, mechanisms (a), (b), and (d) cannot be discarded as possible explanations of the observed stimulating or protective effect of PAC against $\mathrm{Cr}(\mathrm{VI})$ toxicity. Our results showed that the $\mathrm{Cr}(\mathrm{VI})$ removal using PAC alone (System 5) was negligible in comparison to Systems 2 (activated sludge-lactose) and 4 (activated sludge-lactose-PAC), thus, the hypothesis (e) about the adsorption of $\mathrm{Cr}(\mathrm{VI})$ on the PAC surface could be discarded.

The protective effect of PAC on the metabolic activity of the micro-organisms in the presence of $\mathrm{Cr}(\mathrm{VI})$ was analysed by measuring the activated sludge respiration rate. The measurements were performed under different initial $\mathrm{Cr}(\mathrm{VI})$ concentrations in the absence and in the presence of PAC. Results were expressed as a fraction of the respiration rate (Fr) as defined in Eq. (4). Figure 6 shows that Fr values in the presence of PAC were higher than in its absence for all the tested $\mathrm{Cr}(\mathrm{VI})$ concentrations. Therefore, the addition of PAC protected the biomass

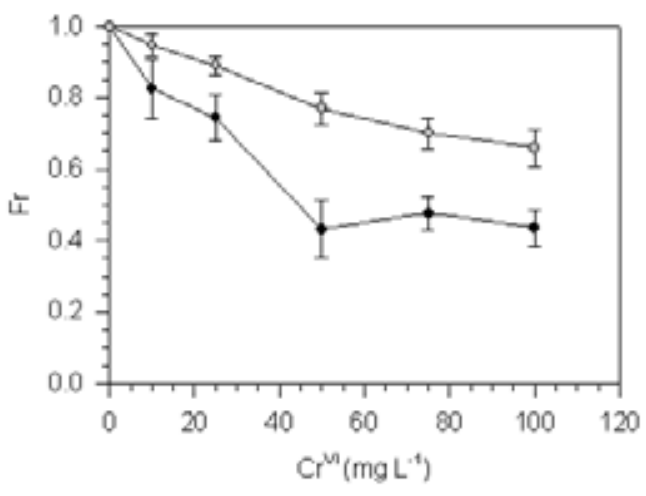

Figure 6

Biomass respiratory activity fraction $(F r)$ as a function of $\mathrm{Cr}(\mathrm{VI})$ concentration in the absence (black) and presence (grey) of PAC (4 g/l). Results represent the mean value $\pm S D$ from two independent assays.

decreasing the loss of metabolic activity of the activated sludge due to the $\operatorname{Cr}(\mathrm{VI})$ toxicity. Sher et al. (2000) studied the effect of zinc on activated sludge with and without PAC addition. These authors found that although zinc was not adsorbed on the activated carbon, the micro-organisms in this system resisted the zinc toxicity better than in the system containing activated sludge without PAC.

\section{Conclusions}

Activated sludges are capable of removing $\mathrm{Cr}(\mathrm{VI})$ via its reduction to $\mathrm{Cr}$ (III) only if a suitable electron donor (such as lactose) is available. For initial $\mathrm{Cr}(\mathrm{VI})$ concentration lower than $10 \mathrm{mg} / \ell$, biomass alone can remove $100 \%$ of the $\mathrm{Cr}(\mathrm{VI})$. However, for higher initial $\mathrm{Cr}(\mathrm{VI})$ concentrations, removal efficiencies of system with PAC were higher than $\mathrm{R}_{\mathrm{E}}$ corresponding to system without PAC. In addition, as the initial $\mathrm{Cr}(\mathrm{VI})$ concentration increased, the rate of $\mathrm{Cr}(\mathrm{VI})$ removal and $\mathrm{R}_{\mathrm{E}}$ values decreased reflecting loss of metabolic activity of the activated sludge due to the toxicity of $\operatorname{Cr}(\mathrm{VI})$; however, this inhibition was less in systems with PAC.

Whereas the removal of $\mathrm{Cr}(\mathrm{VI})$ using PAC alone is negligible, the addition of PAC can improve the biological reduction of $\mathrm{Cr}(\mathrm{VI})$ due to the stimulating or protective effect against the $\mathrm{Cr}(\mathrm{VI})$ toxicity. This protective effect was also observed in respiratory activity of the biomass.

Thus, it was necessary for the biomass, a suitable electron donor and PAC to be present simultaneously in order to achieve high $\mathrm{Cr}(\mathrm{VI})$ removal efficiencies when the $\mathrm{Cr}(\mathrm{VI})$ initial concentration was higher than $10 \mathrm{mg} / \ell$.

\section{Acknowledgements}

The financial support given by Consejo Nacional de Investigaciones Científicas y Técnicas (CONICET), Agencia Nacional de Promoción Científica y Tecnológica (Proyecto 09-11211) and Universidad Nacional de La Plata, is gratefully acknowledged.

\section{References}

ASATIANI NV, ABULADZE MK, KARTVELISHVILI TM, BAKRADZE NG, SAPOJNIKOVA NA, TSIBAKHASHVILI NY, TABATADZE LV, LEJAVA LV, ASANISHVILI LL and HOLMAN H (2004) Effect of chromium (VI) action on Arthrobacter oxydans. Current Microbiol. 49 321-326.

BERTOLA NC, BEVILACQUA AE and ZARITZKY NE (2001) Mod- 
elling kinetic parameters of a dairy wastes system treated in a labscale activated sludge reactor. Proc. 3rd IWA Int. Spec. Conf. on Microorganisms in Activated Sludge and Biofilm Processes. Available on CD (paper $\mathrm{N}^{\circ} 113$ ).

BEUKES JP, PIENAAR JJ and LACHMANN G (2000) The reduction of hexavalent chromium by sulphite in wastewater - An explanation of the observed reactivity pattern. Water SA 26 (3) 393-396.

BOJIC A, PURENOVIC M and BOJIC D (2004) Removal of chromium (VI) from water by micro-alloyed aluminium composite (MAlC) under flow conditions. Water SA 30 (3) 353-360.

BOPP LH and EHRLICH HL (1988) Chromate resistance and reduction in Pseudomonas fluorescens strain LB300. Arch. Microbiol. 150 426-431.

CHUA H (1998) Effects of trace chromium on organic adsorption capacity and organic removal in activated sludge. Sci. Total Environ. 214 239-245.

CLARK DP (1994) Chromate reductase activity of Enterobacter aerogenes is induced by nitrite. FEMS Microbiol. Lett. 122 233-238.

CONTRERAS EM, BERTOLA NC, GIANNUZZI L and ZARITZKY NE (2002) A modified methods to determine biomass concentration as COD in pure cultures and in activated sludge systems. Water SA 28 463-467.

COSTA C and MÁRQUEZ MC (1998) Kinetics of the PACT process. Water Res. 32 107-114.

DEMIRBAS E, KOBYA M, SENTURK E and OZKAN T (2004) Adsorption kinetics for the removal of chromium (VI) from aqueous solutions on the activated carbons prepared from agricultural wastes. Water SA 30 (4) 533-540.

FIGUEIREDO JL, PEREIRA MFR and FREITAS JJM (1999) Modification of the surface chemistry of activated carbons. Carbon 37 1379-1389.

GARBISU C, ALKORTA I, LLAMA MJ and SERRA JL (1998) Aerobic chromate reduction by Bacillus subtilis. Biodegradation 9 133141.

HEDGECOTT S (1994) Prioritization and standards for hazardous chemicals. In: Calow, P. (ed.) Handbook of Ecotoxicology. Blackwell Scientific Publications, Oxford. 378-382.

HORITSU H, FUTO S, MIYAZAWA Y, OGAI S and KAWAI K (1987) Enzymatic reduction of hexavalent chromium by hexavalent chromium tolerant Pseudomonas ambigua G-1. Agric. Biol. Chem. 51 2417-2420.

IMAI A and GLOYNA EF (1990) Effects of pH and oxidation state of chromium on the behavior of chromium in the activated sludge process. Water Res. 24 1143-1150.

ISHIBASHI Y, CERVANTES C and SILVER S (1990) Chromium reduction in Pseudomonas putida. Appl. Environ. Microbiol. 56 2268-2270.

KALINSKE AA (1972) Enhancement of biological oxidation of organic wastes using activated carbon in microbial suspension. Water Sewage Works 119 62-64.

KATZ SA and SALEM H (1994) The Biological and Environmental Chemistry of Chromium. VCH Publishers, Inc. New York, USA.

LI AYL and DIGIANO FA (1983) Availability of sorbed substrate for microbial degradation on granular activated carbon. J. WPCF. 55 392-399.

LOVLEY DR and PHILLIPS EJP (1994) Reduction of chromate by Desulfovibrio vulgaris and its $\mathrm{C}_{3}$ Cytochrome. Appl. Environ. Microbiol. 60 726-728.

MADONI P, DAVOLI D and GUGLIELMI L (1999) Response of SOUR and AUR to heavy metal contamination in activated sludge. Water Res. 33 2459-2464.

MONDACA MA, CAMPOS V, MORAGA R and ZAROR CA (2002) Chromate reduction in Serratia marcescens isolated from tannery effluent and potential application for bioremediation of chromate pollution. The Scientific World J. 2 972-977.

MORINAGA H, NISHIJIMA W and OKADA M (2003). Stimulation of bacterial activity by the addition of different PACs. Environ. Technol. 24 179-186.

MYERS CR, CARSTENS BP, ANTHOLINE WE and MYERS MJ (2000) Chromium(VI) reductase activity is associated with the cytoplasmic membrane of anaerobically grown Shewanella putre- fasciens MR-1. J. Appl. Microbiol. 88 96-106.

NEPPLE BB, KESSI J and BACHOFEN R (2002) Chromate reduction by Rhodobacter sphaeroides. J. Ind. Microb. Biotechnol. 25 198203.

OKADA M, MORINAGA H and NISHIJIMA W (2000) Activated carbon as better habitat for water and wastewater treatment. Water Sci. Technol. 42 149-154.

ORSHANSKY F and NARKIS N (1997) Characteristics of organics removal by PACT simultaneous adsorption and biodegradation. Water Res. 31 391-398.

PHILIP L, IYENGAR L and VENKOBACHAR C (1998) Cr(VI) reduction by Bacillus coagulans isolated from contaminated soils. J. Environ. Eng. 124 1165-1170.

REGE MA, PETERSEN JN, JOHNSTONE DL, TURICK CE, YONGE DR and APEL WA (1997) Bacterial reduction of hexavalent chromium by Enterobacter cloacae strain HO1 grown on sucrose. Biotechnol. Lett. 19 691-694.

ROS M (1993) Respirometry of Activated Sludge. Technomic Publishing Co., Inc. Basel, Switzerland.

SCHMUHL R, KRIEG HM and KEIZER K (2001) Adsorption of $\mathrm{Cu}(\mathrm{II})$ and $\mathrm{Cr}(\mathrm{VI})$ ions by chitosan: Kinetics and equilibrium studies. Water SA 27 (1) 1-8.

SHEN H and WANG YT (1994) Biological reduction of chromium by $E$. coli. J. Environ. Eng. 120 60-572.

SHEN H and WANG YT (1995) Hexavalent chromium removal in twostage bioreactor system. J. Environ. Eng. 121 798-803.

SHER MI, ARBUCKLE WB and SHEN Z (2000) Oxygen uptake rate inhibition with PACT ${ }^{\mathrm{TM}}$ sludge. J Hazard. Mat. B73 129-142.

STANDARD METHODS (1989) Standard Methods for the Examination of Water and Wastewater (17 $7^{\text {th }}$ edn.). American Public Health Association (APHA). Washington DC.

STASINAKIS AS, MAMAIS D, THOMAIDIS N and LEKKAS TD (2002) Effect of chromium (VI) on bacterial kinetics of heterotrophic biomass of activated sludge. Water Res. 36 3341-3349.

STASINAKIS AS, THOMAIDIS NS, MAMAIS D, KARIVALI M and LEKKAS TD (2003) Chromium species behaviour in the activated sludge process. Chemosphere 52 1059-1067.

STASINAKIS AS, THOMAIDIS NS, MAMAIS D, KARIVALI M and LEKKAS TD (2004) Investigation of $\mathrm{Cr}(\mathrm{VI})$ reduction in continuous-flow activated sludge systems. Chemosphere 57 1069-1077.

SUBLETTE KL, SNIDER EH and SYLVESTER ND (1982) A review of the mechanism of PAC enhancement of activated sludge treatment. Water Res. 16 1075-1082.

TANIGUCHI H, NISHIJIMA W, MURAKAMI A, OKADA M and HOSOMI M (1993) Effects of the powdered activated carbon on an activated sludge process. J. Japan Soc. Water Environ. 16 577-584.

VANKOVÁ S, KUPEE J and HOFFMANN J (1999) Toxicity of chromium to activated sludge. Ecotoxicol. Environmen. Safety 42 1621.

VANROLLEGHEM PA, KONG Z, ROMBOUTS G and VERSTRAETE W (1994) An on-line respirographic biosensor for the characterization of load and toxicity of wastewaters. J Chem. Tech. Biotechnol. 59 321-333.

USEPA (1998a) Toxicological Review of Hexavalent Chromium (CAS No. 18540-29-9) U.S. Environmental Protection Agency. Washington D.C.

USEPA (1998b) Toxicological Review of Trivalent Chromium (CAS No. 16065-83-1) U.S. Environmental Protection Agency. Washington D.C.

WANG P, MORI T, TODA K and OHTAKE H (1990) Membrane-associated chromate reductase activity from Enterobacter cloacae. J. Bacteriol. 172 1670-1672.

WANG Y and SHEN H (1997) Modelling Cr(VI) reduction by pure bacterial cultures. Water Res. 31 727-732.

WANG Y and XIAO C (1995) Factors affecting hexavalent chromium reduction in pure cultures of bacteria. Water Res. 29 2467-2474.

YETIS U, DEMIRER GN and GOKCAY CF (1999) Effect of chromium (VI) on the biomass yield of activated sludge. Enzyme Microb. Technol. 25 48-54.

YING WC and WEBER EJ (Jr) (1979) Bio-physicochemical adsorption model systems for wastewater treatment. J. WPCF. 51 2661-2677. 